ARTIGOS

\title{
Os necrológios e a educação da criança pela família na província do Paraná (1853-1889)
}

\section{The obituaries and the education of children by their families in the province of Paraná (1853-1889)}

Juarez José Tuchinski dos Anjos ${ }^{i}$

¿Universidade de Brasília, Brasília, DF, Brasil. juarezdosanjos@yahoo.com.br

\section{Resumo}

O artigo apresenta parte dos resultados de uma pesquisa de doutorado que investigou a educação da criança pela família no século XIX, na Província do Paraná (1853-1889). Adotando o método de pesquisa histórico-documental, o objetivo aqui é interrogar um tipo de fonte em particular - os necrológios publicados em jornais - visando construir uma definição dessa educação dada pelos pais aos seus filhos, no tempo da infância. As conclusões apontam que a educação da criança pela família parece ter sido uma prática social e cultural, para a aquisição de atitudes e comportamentos, ora caros à organização e às necessidades das famílias, ora vistos como baluarte para a sociedade em que elas viveram.

Palavras-chave: educação, família, século XIX, fontes, necrológios

\section{Abstract}

The article introduces part of the results of a doctoral research that investigated the education of children by their families during the 19th century in the Province of Parana (1853-1889). It aims at questioning a particular type of source - obituaries published in newspapers - in order to build a definition of that education provided by parents to children during childhood. The first part introduces and theorizes the necrological testimony as a source. Then it describes one of the historical problems and the questions to which such evidence was submitted. The third part introduces some historical interpretations to the presented problem based on obituaries published in newspapers of the Province of Paraná.

Keywords: education, family, 19th century, sources, obituaries 


\section{pro.posıções}

\section{Introdução}

A historiografia recente tem demonstrado que, apesar das iniciativas setecentistas de instauração de um ensino público no Brasil por ocasião das Reformas Pombalinas (Fonseca, 2011), foi somente no século XIX que o País, então independente, deu início de forma mais sistemática ao processo de produção da escola primária como lugar privilegiado de formação da criança no tempo da infância (Inácio, Faria Filho, Rosa, \& Sales, 2006; Gouvêa, 2004; Veiga, 2008). Contudo, apesar do inegável crescimento do número de escolas (tanto públicas quanto particulares), da paulatina afirmação da forma escolar e do processo de escolarização do social então posto em movimento (Faria Filho, 2008), ao final do período imperial, a escola primária, fosse pública ou particular, era apenas uma dentre outras instâncias de educação da criança. Embora importante no projeto de construção da nação engendrado ao longo do Império (importância que como historiador da educação não ignoro e está entre as razões que têm me motivado a pesquisar, em outros momentos, a história da escolarização), não era aquela de maior alcance na educação das gerações mais novas. Mesmo um historiador da educação monarquista como José Ricardo Pires de Almeida, que escreveu a primeira história da educação sistematizada, não pôde, apesar de seu ufanismo e engajamento com o regime, deixar de reconhecer essa limitação de alcance da educação escolar no Brasil oitocentista, como observa a respeito da escrita almediana Moysés Kuhlmann Jr (1999). Isso, sem dúvida, porque, como bem observou Maria Elisabeth Blanck Miguel (2011), a escola ainda não era vista pela maior parte da população como uma instituição social necessária.

Uma instituição educativa bem mais forte e consolidada que a escola, naquele momento, era a família ${ }^{1}$. Todavia, sobre os modos como ela educava e, com isso, oferecia resistências aos novos modelos de socialização representados pela escola, é um tema sobre o qual a historiografia da educação sobre o Oitocentos ainda tem muito a pesquisar, como apontam balanços de área e estados da arte (Bastos, 2006; Faria Filho, 2008; Gondra \& Schueller, 2008; Lopes \& Galvão, 2010; Monarcha, 2007). Uma das dificuldades para o

\footnotetext{
${ }^{1}$ A família a que me refiro é a chamada família nuclear moderna que, mesmo podendo ter muitas formas família extensa, família monoparental, dentre outras -, era formada pelas figuras do pai e da mãe (ou aqueles que lhes fazem as vezes) e dos filhos. Ocupo-me somente da família livre, não abordando aqui a família escrava.
} 


\section{pro.posıções \\ e-ISSN 1980-6248}

investimento nessa frente de trabalho, sem dúvida, é a que diz respeito à produção das fontes que permitam, por meio da lógica histórica de que fala E. P. Thompson (2009a), construir interpretações sobre tal fenômeno.

Diferentes das fontes relativas à história da escola - mais conhecidas e, quase sempre, públicas, uma vez que, produzidas no âmbito estatal, repousam nos arquivos públicos da União, dos estados e dos municípios ou mesmo de instituições escolares -, as fontes para a escrita da história da educação da criança pela família no século XIX dizem respeito, em grande parte, ao foro privado, constituindo-se em documentação mais difícil de rastrear e, muitas vezes, perdida para sempre pelo descaso das famílias com sua própria história e memória. Mesmo quando preservadas e conservadas, nem sempre são colocadas à disposição do historiador, por conta de interesses familiares ou receio de expor ao público elementos considerados íntimos ou, ainda, evidências que, ao serem questionados pela lógica histórica, descontruam as memórias alimentadas por determinadas famílias sobre seu passado no quadro das sociedades em que estão inseridas. Diante disso, resta ao historiador contar com a sorte de encontrar acervos familiares disponíveis ou, então, usar de criatividade para a produção de suas fontes, buscando evidências das experiências familiares nos mais diversos materiais.

Este artigo apresenta parte dos resultados de uma pesquisa de doutorado que investigou a educação da criança pela família, analisando o problema histórico a partir das experiências ocorridas na Província do Paraná, entre os anos de 1853 a 1889. Fazendo um recorte nessa pesquisa mais ampla e diante das considerações acima tecidas, o objetivo aqui é, pela interrogação de um tipo de fonte em particular - os necrológios publicados em jornais -, construir uma definição dessa educação ${ }^{2}$ dada pelos pais aos seus filhos, na infância, ao longo do século XIX paranaense.

No encalço desse objetivo, na primeira parte do artigo, realizo uma apresentação dos necrológios como fonte, pari passu à sua teorização, isto é, reflexão sobre as possibilidades e os limites do seu testemunho para a pesquisa sobre a educação da criança pela família no século XIX. Na segunda parte, discorro sobre um dos problemas históricos que precisei enfrentar ao longo da pesquisa de doutorado que originou este artigo. $\mathrm{Na}$

2Por educação entende-se, aqui, aquela não escolarizada, de caráter mais difuso, dada pelas famílias. Não me refiro aqui à instrução das primeiras letras feita em casa por preceptores e professores particulares, estudada por Maria Celi Vasconcelos (2005) para o contexto do Rio de Janeiro e Ana Maria Rufino Gilies (2014) para o contexto paranaense. 


\section{pro.posıções \\ e-ISSN 1980-6248}

terceira parte, apresento algumas interpretações que o testemunho necrológico permitiu construir acerca desse problema levantado. Ao final, encerro com breves considerações, a modo de conclusão.

\section{O testemunho necrológico: produzindo uma evidência histórica}

Desde a chegada da imprensa ao Paraná, em abril de 1854 (quando foi fundado seu primeiro jornal, o Dezenove de Dezembro, que circularia quase ininterruptamente até 1890), a coluna "Publicações a pedido"3, de praticamente todos os periódicos que foram aparecendo desde então (com um aumento significativo a partir da década de 1870), sempre esteve aberta a receber, por ocasião do falecimento de alguém e mediante módica contribuição, um texto, às vezes breve outras vezes longo, tecendo o elogio fúnebre ao falecido. Esse tipo de texto é o que chamamos de necrológio.

Foi um texto desse tipo que um amigo de João de Paula Xavier - morador da Vila do Príncipe -, que vítima de uma congestão cerebral, falecera na noite de 6 de dezembro de 1862, redigiu. Três dias depois do passamento, a 9 de dezembro, o leal amigo Luiz Manoel da Cunha, provavelmente vindo de velar e enterrar o morto junto com os familiares daquele, escreveu um extenso elogio, destacando as virtudes do finado, manuscrito que foi publicado 11 dias mais tarde, em O Correio Oficial. Após expressar resignação ante a

\footnotetext{
${ }^{3} \mathrm{Os}$ jornais do século XIX, embora diferentes dos hodiernos e mesmo entre si já naquela época, apresentavam uma estrutura bastante similar. Quatro eram as partes principais: o "editorial" (não sob esse nome, mas sendo, sem dúvida, um texto de opinião escrito pela redação do jornal), as notícias, as publicações a pedido e os anúncios (via de regra, publicados na última página). Jornais que tinham contratos com o governo - como foi o caso de alguns periódicos paranaenses, dentre os quais $O$ Dezenove de Dezembro contavam, ainda, com uma "parte oficial", na qual os atos da administração provincial e imperial eram publicados. Geralmente, o "editorial" e as notícias eram de responsabilidade do redator ao passo que as publicações a pedido e os anúncios eram veiculados mediante pagamento e sob a responsabilidade dos seus anunciantes. Mesmo que nem sempre os nomes dos autores fossem publicados junto dos "a pedido" e "anúncios", por força das determinações do Código Criminal de 1831, o redator sempre tinha em seu poder o original enviado, com a devida assinatura de responsabilidade legal. Por conta disso, fica claro, desde já, que a imprensa é um "lugar para a história" (Farge, 1999) no qual se podem capturar não apenas as vozes de intelectuais e redatores de jornais, mas de muitas outras categorias sociais que, por meio de publicações a pedido e anúncios, deixaram nesse impresso, em algum grau, marcas de suas existências. Nesse sentido, os trabalhos de Gilberto Freyre (1963) sobre os escravos em anúncios de jornais brasileiros e de E. P. Thompson (2009b) sobre a venda de esposas na Inglaterra me parecem modelares.
} 


\section{pro.posıções}

e-ISSN 1980-6248

vontade do Altíssimo, manifestar sua dor e descrever as circunstâncias da morte de João de Paula Xavier, passa a relatar o comportamento do amigo na intimidade da família:

Pai carinhoso, esposo modelo, amigo sincero, alma generosa e benfazeja, caráter nobre e honrado e cidadão prestável, eis as verdadeiras qualidades que formavam o homem que a sociedade perdeu e cujo vácuo dificilmente será preenchido. Nele tinham os risonhos filhinhos a garantia de um risonho porvir; a esposa o amante extremoso e o tipo de todas as virtudes... (Necrológio, 1861, dezembro, 20)

Os necrológios, como se percebe, oferecem inúmeras informações sobre a vida privada dos falecidos. Tornam-se relevantes, portanto, na tentativa de apreender dados sobre o cotidiano de grupos familiares que, à exceção desse documento, nenhum outro legaram de si ou sobre si, sendo, destarte, uma possível solução à carência de fontes para a história da educação da criança pela família, na medida em que, mesmo involuntariamente, descrevem aspectos importantes da vida e da história das famílias e de seus membros. Nesse aspecto, a pesquisa sobre a história da educação da criança pela família parece situarse naquele quadro de renovação metodológica proposto pela história cultural, que tem como uma de suas características, lembram-nos Clarice Nunes e Marta Carvalho (1993), a exigência da inventividade de fontes e refinamento de olhar por parte do historiador. Inventividade e refinamento que teremos de exercitar aqui.

Muitas vezes os necrológicos aproximam-se do gênero biográfico, tentando retratar o que teria sido a trajetória do morto desde o berço até o túmulo, descrevendo momentos significativos da sua vida em casa e na sociedade. Por conta disso, colocam-nos diante daqueles mesmos problemas da narrativa biográfica, já apontados por Pierre Bourdieu (2001) sob a denominação de "ilusão biográfica". Esse sociólogo, por sinal, ajuda-nos a pensar alguns dos limites do necrológio como fonte histórica. Ao narrar a vida do morto como uma trajetória linear, esses textos, como toda biografia, estabelecem artificialmente alguns marcos significativos daquela vida que se extinguiu, mas, ao mesmo tempo, ignoram as contradições e as negações de que ela também foi feita, com vistas ao estabelecimento de sentido e coesão que o autor da necrologia, por meio de uma operação escriturística, procurou construir e legar aos pósteros. Os necrológios encaixam-se perfeitamente, por essa razão, naquela categoria de documento-monumento de que fala Jacques Le Goff 


\section{pro.posições}

(2003), representando não mais que uma construção de memória sobre uma vida e, não necessariamente, correspondem ao que ela foi, efetivamente, na experiência da história.

Com essas considerações não quero subestimar a riqueza dos necrológios como fonte para a história da educação da criança pela família no século XIX. Pelo contrário, penso que esses limites nos fornecem os parâmetros pelos quais a crítica desses documentos deve ser feita, para serem, então, interrogados como evidência histórica. Os textos do gênero necrológico, apesar de trabalharem muitas vezes nos limites da "ilusão biográfica" e constituírem-se, sobretudo, em “documento-monumento”, não deixam de ser duplamente testemunhos de realidades em que foram produzidos e que podem ser neles apreendidas por meio do questionamento e da indagação historiográfica.

De fato, ao mesmo tempo em que os necrológios expressam nos seus elogios valores que teriam sido vividos pelos mortos (reportando-nos, assim, à dimensão de ilusão biográfica neles contida), nos falam dos valores caros aos vivos e que o são a tal ponto que acabam selecionados por estes para construir a imagem do pai, do esposo e do cidadão ideal, erigindo-os, dessa forma e somente por carregar tais aspectos, em documentomonumento. Assim, diante da morte, eles fazem emergir um mundo de coisas não ditas habitualmente em outras circunstâncias, mas que, agora, o pudor permite que sejam reveladas: as (boas) atitudes e comportamentos na intimidade, os desvelos do pai pelos filhos, do esposo pela esposa. Se o relato harmoniza ou oculta os erros e os deslizes do que partiu, como ocorre também nas biografias, não temos como saber. Mas, por outro lado, ele nos informa que o carinho, a sinceridade, a presteza estavam entre os comportamentos considerados adequados e exemplares de alguém que bem desempenhou a função paterna, marital e cidadã no século XIX. Ao confirmarem aquilo que Norbert Elias (2002) escrevia em seu ensaio sobre a morte, de que esta não é um problema dos mortos, mas dos vivos, eles nos permitem, na voz dos vivos falando dos mortos, ouvir a voz dos vivos falando sobre as mais diversas circunstâncias da vida e, em algumas ocasiões, da educação que estes, no papel de pais e mães, deram aos filhos que agora deixaram na terra (alguns ainda na infância e na orfandade e outros, já adultos, homens e mulheres feitos).

Contudo, como documentos-monumentos que são os necrológios, sua crítica deve ser feita, também e sempre que possível, no contraste entre diferentes textos do gênero, 


\section{pro.posições}

bem como com outros documentos da época, que permitam avançar ou mesmo "demolir" alguns sentidos e significados que o elogio fúnebre, na ânsia de enaltecer a memória do falecido, acabou por obscurecer ou diluir por meio de uma narrativa. Logicamente, jamais teremos como confrontar todas as informações contidas num necrológico, mas teremos, ao menos, como perceber os sentidos socialmente atribuídos a gestos e práticas familiares que não eram apenas individuais, mas sociais, como era o caso da educação da criança pela família.

Assim munidos por esses elementos de crítica documental, nos dedicaremos, na terceira parte do artigo, a interrogar o testemunho necrológico. Antes disso, porém, é preciso formular melhor o tipo de questão e interrogações a que ele será submetido, já que, conforme nos ensinou Marc Bloch (2011), um documento não fala por si até que seja interrogado. Como observava Lucien Febvre (1989), "se não há problemas, não há história. Apenas narrações, compilações” (p. 31). E a lógica histórica, esclarece E. P. Thompson (2009a), ancora-se, sobretudo, no diálogo entre a evidência, a teoria/hipóteses e as questões que, nesse processo, vão sendo formuladas pelo historiador. Essas questões, no caso em tela, resumem-se no problema histórico que delinearei a seguir.

\section{Educação da criança pela família no século XIX: em busca de uma definição}

Escrevemos história (s) da Educação. Mas o que entendemos por educação? Ou melhor, que experiências históricas esperamos encontrar, sob o signo dessa palavra em cada época histórica, quando, parafraseando Georges Duby (1989), nós retiramos e mergulhamos no silêncio para tentar, mal-informados, perdidos entre pistas embrulhadas, embaciadas, discordantes, compreender o que se passou há séculos?

Quando iniciava a pesquisa de doutorado, entendi que seria fundamental definir o que seria a educação que, dada pela família à criança no século XIX, eu desejava investigar e compreender. Porém, onde buscar tal definição? Antes mesmo da inspiradora leitura de A história continua (Duby, 1993), já estava convencido de que os conceitos em história não podem ser elaborados a priori, mas devem, na medida do possível e dos testemunhos 


\section{pro.posıções \\ e-ISSN 1980-6248}

disponíveis, ser produzidos a partir das experiências vividas pelos sujeitos que queremos investigar, para não cair no anacronismo e conseguir fazer da definição uma ferramenta útil para a interpretação histórica4.

Assim, num recurso que então pareceu adequado, recorri aos dicionários do século XVIII e do século XIX, para encontrar neles uma definição de educação, assentada na noção de criação dos filhos em direção dos costumes (Bluteau, 1728) 5, "criação que se faz de alguém ou que se lhe dá, ensino de coisas que aperfeiçoam o entendimento ou serem de dirigir à vontade e também do que respeita ao decoro” (Morais da Silva, 1813), ou criação, como concebe Fonseca (1848). Contudo, rapidamente essa definição muito pouca serventia revelou ter, per se, quando chegou a hora de compreendê-la na complexa realidade do passado.

Diferente do uso que queria fazer do dicionário e que, via de regra, é tendência entre nós historiadores - consultar o entendimento de uma determinada palavra em determinado período histórico para não incorrer em anacronismo, dos pecados do ofício o mais imperdoável (Febvre, 2009) -, não era bem assim que ele "funcionava" no século XIX, conforme alertam os historiadores da lexicografia José Horta Nunes (2006) e Telmo Verdelho (2002), dentre outros. A partir desses estudos, compreendi que os leitores do Oitocentos consultavam uma palavra no dicionário para saber não o que significava no seu cotidiano, mas o que é que, segundo os autores mais respeitados da língua portuguesa, ela significava ou deveria significar. Ao confrontar diferentes dicionários, inclusive, observei que neles se operava uma verdadeira luta de representações (Chartier, 2002) em torno dos sentidos das palavras - e "educação" era apenas um dos objetos dessa disputa - coisa que, embora interessante e posteriormente estudada por mim, naquele momento, ia além da necessidade inicial de uma definição mais próxima dos lares das famílias que das mesas de

\footnotetext{
${ }^{4}$ Sobre a cautela necessária da parte do historiador para evitar o anacronismo, Duby (1993) recorda-nos o alerta de Lucien Febvre de que "cada época tem sua própria visão de mundo, que as maneiras de sentir e pensar variam com o tempo e que, em consequência, o historiador é solicitado a se precaver o quanto puder das suas, sob pena de nada compreender.” (, pp. 85-86). Se o alerta é válido para todo fenômeno histórico, o é mais ainda para a educação, um fenômeno presente nas sociedades tanto ontem quanto hoje, mas com significados diferenciados.

${ }^{5} \mathrm{O}$ recurso a Rafael Bluteau, num dicionário setecentista, justificou-se pelo fato de suas definições terem servido de bases tanto para Morais da Silva como José da Fonseca, dentre outros dicionaristas do Oitocentos.
} 


\section{pro.posıções \\ eISSN 1980-6248}

estudo dos dicionaristas. Era preciso, assim, encarar o problema histórico de outra perspectiva.

Ao tratar das características da análise histórica, Marc Bloch considerou que uma das suas necessárias etapas é a que diz respeito à nomenclatura. Comparando a vantagem do químico - que produz palavras específicas para os fenômenos que analisa - apontou a desvantagem do historiador, que investiga fenômenos que tem por agentes os homens:

Para dar nomes a seus atos, a suas crenças e aos diversos aspectos de sua vida de sociedade, os homens não esperam para vê-los tornarem-se o objeto de uma pesquisa desinteressada. A história recebe seu vocabulário, portanto, em sua maior parte, a própria matéria do seu estudo. [Ënfase adicionada]. (p. 136)

Diante dessa afirmação, aparentemente, bastaria que o historiador buscasse se aproximar do significado das palavras em cada época (e não é justamente, essa, a intenção do recurso aos dicionaristas?). Todavia, Bloch (2011) alerta que o decalque da terminologia do passado só à primeira vista se revela um procedimento seguro, por uma dupla razão: embora um nome permaneça, seu conteúdo pode variar; embora o nome mude, o sentido de uma palavra pode continuar o mesmo. Ainda assim, o historiador jamais pode abrir mão de servir-se das palavras para empreender sua análise. A questão, então, passa a ser não tanto da semântica da palavra, mas, sobretudo, do uso que dela é feito, em cada tempo e lugar (Bloch, 2011), já que produzida pelos homens, está a serviço deles. Dessa forma, o modo mais adequado de tratar a palavra, que sempre busca exprimir uma ação humana, é compreender que

o vocabulário dos documentos não é, a seu modo, nada mais que um testemunho: precioso, sem dúvida, entre todos; mas, como todos os testemunhos, imperfeito; portanto, sujeito à crítica. Cada termo importante, cada figura de estilo característica, torna-se um verdadeiro instrumento de conhecimento, bastando ser confrontado uma única vez com seu ambiente; recolocado no uso da época, do meio ou do autor. (p. 142)

Passei a conceber que essa proposição de Bloch - de buscar o significado da palavra não no verbete que a define, mas no uso que dela fazem os diferentes grupos humanos - transformava o limite do dicionário e da definição de educação no século XIX em potencialidade para a análise histórica, por duas razões. Primeiramente, não obstante a certeza de que a definição do dicionarista nunca consiga abarcar a dinâmica da realidade, ela 
precisou dialogar, ainda que minimamente, com as mesmas realidades sobre as quais certas autoridades em que se ancoravam - a literatura, por exemplo - estavam embasadas. Em segundo lugar - e aqui recordo a acertada posição de Carlo Ginzburg (2008) -, em matéria de crítica de testemunhos, nunca é bom “jogar a criança fora, junto com a água da bacia” (p. 16), não devendo o historiador desconsiderar nenhuma possibilidade das evidências, que de um jeito ou outro, sempre informam alguma coisa - mesmo que por meio de indícios - sobre a época em que foram produzidas.

Se voltarmos às definições dos dicionaristas, veremos que, sob o signo da palavra educação, eles nos falam tanto de uma prática social, na medida em que o seu conceito remete à relação de diferentes grupos de pessoas - os filhos que deveriam ser criados, certamente, pelos pais ou por algum outro adulto (Bluteau, 1728), a criação feita para alguém ou que se lhe dá (Morais da Silva, 1813) - como falam de uma prática cultural, que visava à transmissão de costumes, saberes (as tais coisas que aperfeiçoam o entendimento de que fala o dicionarista Morais da Silva) e normas de conduta, que eram variáveis de acordo com o grupo que educava e era educado, bem como em relação ao tempo ou aos espaços nos quais essa prática era engendrada. Tomando isso como uma hipótese provisória, pude redefinir o problema histórico: a pergunta mais adequada já não era "o que se entendia por educação no século XIX”, mas o que os homens e as mulheres daquele século faziam, que valores e condutas transmitiam, quando acreditavam e se convenciam de que estavam desempenhando a tarefa da educação de seus filhos. As respostas construídas a essa questão apresento a seguir, em forma de narrativa histórica, construída a partir da indagação não mais dos dicionários do século XIX, mas dos necrológios publicados na imprensa do Paraná Provincial. Antes de avançar, porém, cumpre fazer um esclarecimento, relativo à operação historiográfica.

A opção narrativa adotada procura permitir ao leitor aproximar-se do tortuoso caminho percorrido na pesquisa para a construção e a demarcação das significações em torno da educação da criança pela família, conforme mediadas pelo testemunho necrológico, em meio a indícios, vestígios e sinais - para usar a definição clássica de Carlo Ginzburg (1989). Por essa razão, será de forma lenta e indiciária que os nexos entre vestígios e sinais sobre o tema perseguido ganharão visibilidade, sobretudo, nas conclusões do trabalho. Optei por esse caminho pouco convencional por concordar com Giovanni 


\section{pro.posições \\ eISSN 1980-6248}

Levi (1991) que a narrativa, em história, integra o processo de pesquisa, e, ao não ocultar os percalços do caminho, o historiador permite que o leitor participe "de todo o processo de construção do argumento histórico" (p. 153).

\section{A educação da criança pela família na Província do Paraná, segundo os necrológios}

A educação dos filhos teria sido objeto de grande desvelo na vida de Bento Ribeiro Guimarães, morador de Paranaguá. Após uma enfermidade de 14 meses, faleceu a 17 de março de 1870, mas não sem antes ter conseguido assistir ao casamento da filha mais velha (o que é indicador de que outros mais novos ficavam ainda em tenra idade), numa cerimônia realizada em sua casa, época em que, já "quase desprendido das ideias terrenas, era-lhe ao menos grato assegurar o futuro de sua primeira filha" (Necrológio, 1870, abril, 06). Mas, enquanto estava vivo e rijo, Bento Guimarães sempre havia se preocupado por legar a seus filhos "quase todos menores, se não uma fortuna, ao menos uma instrução regular e uma educação condigna de preparar-lhes o espírito para as lides da vida" (Necrológio, 1870, abril, 06). Esse pai, assim, tentou oferecer à sua prole a instrução, provavelmente como aquisição de conhecimentos escolarizados, mas também uma educação, de caráter mais imaterial, objetivando preparar os filhos para as circunstâncias da vida. Essa preparação do espírito podia muito bem consistir no mesmo tipo de educação que, afirmava-se, o próprio finado tinha - de matriz religiosa, uma vez que, quando quase se despedia do mundo dos vivos, era por ser "religioso por índole e educação, [que] esperava calmo e resignado o momento solene. É o passamento do justo" (Necrológio, 1870, abril, $06)$.

Se na casa dos Guimarães a educação paterna tinha cores imateriais e quiçá religiosas, o tenente João Manoel de Paula imprimia a ela marcas um pouco mais terrenas e pragmáticas. Foi surpreendido pela morte: enquanto se encaminhava para abrir seu negócio, lá pelas nove horas de uma manhã de dezembro de 1862, sofreu o que foi considerado pelos médicos uma congestão cerebral, que o fez atravessar uma agonia de três 
horas, durante as quais teve tempo de preocupar-se com o futuro dos filhos, rogando aos amigos que deles se apiedassem. Um destes, que escreveu mais tarde o necrológio, salientou que o tenente João Manoel fora sempre dedicado ao trabalho rude (que lhe fora ingrato no fim da vida, já que seus negócios passavam por uma "tempestade comercial") e à família, pondo "todo o seu esmero na educação dos filhos, observando a mais severa economia e a mais estrita ordem no manejo da casa" (Necrológio, 1862, dezembro, 24). Como se percebe, no caso em questão, a educação se materializava no ensino da parcimônia e da economia, atitudes fundamentais para uma família que vive e se sustenta por meio do comércio, sobretudo quando os negócios vão mal, como sugere o autor da necrologia.

Os necrológios não destacavam apenas as ações paternas na educação dos filhos, mas também as maternas. Ainda que, quando se tratava de mulheres, tendessem a valorizar mais as atitudes da esposa e a dimensão afetiva própria da função da mãe, às vezes falavam por alto da educação, como no caso de Maria do Sacramento Ribas, que, enquanto estava cheia de vida e mocidade (e não "um cadáver frio e inanimado lançado debaixo da terra"!) "zelando dos interesses de sua família, criava e educava seus filhos" (Necrológio, 1859, janeiro, 08), tratava de prover as suas necessidades físicas através da criação, mas também as morais, por meio da educação. Em outros necrológios, porém, como em relação a Joana Hilária, uma sexagenária senhora, não nascida no Paraná, mas moradora da Província há mais de 30 anos, a ação educacional da finada era mais detalhada: "Era uma senhora de trato ameno nas salas, excelente mãe, cuidando sempre desvelada na educação e instrução de seus filhos. ... Ensinava os seus a amar a virtude e a praticá-la não só com a palavra, mas também com o exemplo" (Necrológio, 1865, março, 04). Aqui, transparecem além do conteúdo da educação - a "virtude" (possivelmente designando uma série de atributos positivos que ornavam o caráter de uma pessoa), os meios pelos quais ela era ensinada: pela palavra e pelo exemplo, pelo dizer e pelo fazer. E tal conduta materna exigia atenção e empenho, evidenciadas pelo "desvelo" com que procurou se desincumbir dessa tarefa própria de uma "boa mãe".

Houve uma ocasião em que o foco do relato necrológico não recaiu sobre a educação dada por uma mulher, mas recebida por ela na infância e da qual toda a sua vida fora testemunho. Balbina Ferreira de Siqueira, ao que parece, uma jovem casada de pouco, 
faleceu em Guarapuava, deixando na terra um "adorado esposo, a idolatrada filhinha e a seus inconsoláveis pais e irmãos" (Necrológio, 1872a, maio, 01). Toda sua vida teria sido uma prova da educação recebida: "filha do muito honrado Major Domingos de Siqueira Cortes, recebeu ela na infância as instruções sublimes do evangelho, adquiriu os hábitos de seus dignos pais e jamais afastando-se da senda trilhada" (Necrológio, 1872a, maio, 01). É claro que a palavra instrução poderia querer significar aquele conjunto de saberes escolarizados (e sabemos que a escola imperial prescrevia dentre suas matérias elementares o ensino religioso e mesmo a instrução doméstica das primeiras letras não abria mão de tal saber). Todavia, na aquisição de hábitos dos pais, isto é, de condutas, atitudes, comportamentos, etc. vindos do Major Cortes e Esposa e transmitidos à filha falecida precocemente, parecemos encontrar o que seja também essa educação mais ampla, que independia da mediação da escola para se fazer sentir na vida de alguém e que, na hora da morte, era a coroa que enaltecia uma conduta feminina.

Detalhar a educação dada pelo pai no elogio fúnebre não era, porém, uma regra em se tratando de homens. De Eduardo Mostaert, proprietário do Hotel Quatro Nações, na capital da Província, apenas se falou que fora "amante de sua família, cuidando com vontade e zelo na educação dos seus filhos" (Necrológio, 1876b, novembro, 13). É bem verdade que, se não houve preocupação em delimitar os modos e as formas que essa educação assumia, o necrológio ressalta que ela estava dentre as qualidades que o haviam tornado conhecido e estimado (Necrológio, 1876b, novembro, 13). Uma referência mais detalhada é a que obtivemos por ocasião da morte de José Pereira Jorge, que, ao falecer em 1880 na capital, exercia a função de amanuense na Secretaria de Polícia. Depois de ser recordado por sua conduta ilibada na vida profissional, tornou-se pública a que guardou na vida familiar, ao ser lembrado que fora "Pai extremoso, que na educação da família nunca se esqueceu de plantar os sãos princípios da religião, assim como aperfeiçoou-a na prática da caridade, único legado que falecendo, deixou aos filhos"(Necrológio, 1880, janeiro, 18). É novamente a matriz religiosa que parece ter conduzido, durante a vida, os ideais educativos desse pai de família. E essa educação foi a única herança que pôde transmitir aos seus. Mas essa inspiração religiosa precisava manifestar-se de maneira concreta nas atitudes que deveria despertar nos filhos: a prática da caridade, que, de acordo com a doutrina católica, faz o par perfeito com a fé. 


\section{pro.posições}

Uma coisa que os necrológios, de modo implícito nos recordam, é que boa parte desses pais e mães, ao falecer, deixou na terra dos vivos gementes et flentes in hac lacrimarum valle, filhos que ainda precisavam de educação. Quem continuaria a tarefa interrompida pela morte? Como essas famílias se reorganizavam para isso?

Em janeiro de 1876, a cidade da Lapa assistiu à passagem do "anjo exterminador", havendo um número de mortes incomum para um mesmo período do ano. Dentre aqueles que tiveram as vidas ceifadas, estavam Joaquina de Paula Westphalen, esposa do promotor público local, e Manoel José Correia de Lacerda. Evidentemente, aproveitando-se do mesmo necrológio para dar conta de comunicar a dor e as circunstâncias das duas mortes, o autor encontrou tempo para mencionar a situação em que ficavam as duas filhinhas que perderam a mãe (vítima de peritonite puerperal, sem dúvida, em função de complicações do parto da mais nova das crianças) e os filhos que não mais veriam o pai. Todavia, o consolo dos pequenos estaria, no caso das meninas, na avó materna, que seria para elas "uma segunda mãe", ao passo que os órfãos de Manoel José Correia de Lacerda encontrariam no irmão mais velho "os braços e carinhos" para ampará-los (Necrológio, 1876a, janeiro, 23). Essa evidência nos deixa entrever, assim, algumas situações que acabavam sendo readaptadas na vida de uma família quando da morte de pai ou mãe. No caso da falta desta última, a avó materna é quem ficaria com a incumbência de ser para elas segunda mãe, permitindo-nos pensar que tudo aquilo que era esperado da mãe que gerou (inclusive a educação) fosse também realizado pela "mãe" que agora faria as vezes daquela que partiu. Já na falta do pai, a situação ficava mais complexa: na situação em tela, o irmão mais velho é que teria de tomar para si a responsabilidade de cuidar dos mais novos e, dentre as incumbências do novo chefe de família, pode ter estado também a educação.

Se na casa de Manoel José os destinos dos filhos se acertariam em família, nem sempre as coisas se ajeitavam assim. Em 1871, faleceu Madame Constance Grilet, imigrante francesa e dona de um hotel e bilhar em Curitiba, deixando quatro filhos menores. Ao que consta, não existiam pessoas próximas a quem pudessem ser confiados, de modo que "O respectivo juiz deu prontas providências para acautelar os interesses daquele estabelecimento e abrigar os órfãos de quaisquer privações" (Necrológio, 1871, setembro, 06). No ano seguinte, foi a família de Arcênio Pompílio de Paula, funcionário da tesouraria provincial, que se viu privada do pai. Deixando ele "sua viúva e três filhos menores sem 
meio algum de subsistência", esperava-se que "o espírito de caridade que distingue os paranaenses, não será indiferente à sorte destes infelizes órfãos. Nós o invocamos em prol deles, oferecendo desde já qualquer auxílio. " (Necrológio, 1872b, setembro, 18). Às vezes, a notícia "mandava recado", sugerindo quem é que deveria assumir esse tipo de responsabilidade. Foi o que se deu em 1868, ano em que repentinamente faleceu José Faria, num domingo, às três horas da tarde, quando se encontrava na porta do seu estabelecimento comercial. Seus negócios iam mal e às suas sete órfãs e à esposa legou a pobreza. "Entretanto" - concluía a notícia - "não se pode deixar de crer que seu sogro, abastado como é, amparará suas infelizes netas" (Necrológio, 1868, maio, 13).

Nessas evidências, um novo personagem talvez possa ter entrado em cena na vida das esposas desoladas e dos órfãos desamparados: o tutor. Como se percebe, a preocupação fundamental nos testemunhos em tela é com o sustento e a proteção dos órfãos, o que, de acordo com a legislação em vigor no Império, seria a função de um tutor, que poderia ser a própria mãe (quando não houvesse uma nomeação feita em vida pelo pai designando o contrário), com a condição de que se mantivesse viúva ou outra pessoa que disso fosse incumbida. Em caso de segundas núpcias, a tutela, quando assumida pela mãe, teria que ser transferida para um terceiro. O fato é que essas evidências nos fazem pensar que, além daquela família formada pela mãe e pelo pai educador ou pelo irmão que assume tal papel, pode ter havido outras em que a educação das crianças ficava sob responsabilidade de um ou outro parente mais próximo, ou ainda, da mãe auxiliada por um tutor. E digo auxiliada porque, diferentemente do que é corrente na historiografia a respeito da tutela, cuja ênfase tem recaído sobre as formas como o tutor se servia do trabalho dos pupilos em proveito próprio ou fazendo do aprendizado de um ofício um modo de educar o tutelado, uma das interpretações correntes da legislação via-o como alguém que devia ir muito além da mera função de provedor e administrador de bens.

O Conselheiro Fiel do Povo, um opúsculo em dois volumes bastante vulgarizado no século XIX pelo seu caráter prático de traduzir as leis para a população brasileira, permitindo-lhe um rápido conhecimento das principais circunstâncias da vida nas quais ficavam sujeitos a uma ou a outra disposição legal (lembrando que elas eram muitas, remontando em vários casos às Ordenações Filipinas, às Leis Extravagantes do Reino de Portugal, à Constituição do Império de 1824 e ao Código Criminal de 1831, além das leis 


\section{pro.posıções}

eISSN 1980-6248

que anualmente eram aprovadas e revogadas pelas Câmaras do Império e publicadas nas famosas coleções de Leis e Decisões do Império do Brasil!), afirmava que tutela consistia "na autoridade e funções de que é revestido o tutor para vigiar a pessoa e bens daquele que não pode defender-se em razão da idade", sendo responsabilidade do tutor "gratuitamente governar a pessoa e bens do pupilo.” (Conselheiro Fiel, 1860, p. 307). E prossegue, afirmando que:

O ofício, autoridade e administração do tutor é quase o mesmo que o de pai, em cujo lugar sucede o tutor. ... Deve o tutor educar o pupilo segundo sua condição e em proporção de seus rendimentos, ou mandar-lhe ensinar o ofício de seu pai e defende-lo tanto em juízo como fora dele. ... Em consequência o pupilo nada pode praticar sem o tutor e este pode tudo fazer sem o pupilo. (pp. 310-311)

Não tenho dúvidas de que, a respeito da função educativa do tutor, os necrológios de modo geral são uma fonte bastante imprecisa. Mas, lidas as preocupações que eles manifestam à luz de como o papel deste homem deveria se fazer sentir na ausência do pai segundo os esclarecimentos do Conselheiro Fiel do Povo, podemos pensar que a ele também cabia a responsabilidade de educar os seus pupilos, tal qual fizera em vida o pai (ou mãe) a quem ele agora substituía. Por essa razão, quem assumia a tutela tinha o dever de não apenas zelar pelos "bens daquele que não pode defender-se em razão da idade" como também de vigiar e governar a pessoa do pupilo, isto é, devia estar atento àquilo que a pequena pessoa, o pupilo, fazia, podendo, inclusive, responder por seus erros e acertos de conduta. Por isso, o "ofício, autoridade e administração do tutor é quase o mesmo que de pai”. E novamente, "educar o pupilo segundo sua condição", de acordo com o lugar social ao qual estava destinado, era responsabilidade de peso entre os complexos encargos assumidos com a tutela.

Dos 132 testamentos existentes e examinados no Fundo do Poder Judiciário do Arquivo Público do Paraná referentes ao período provincial, em apenas um deles encontrei a clara preocupação de um pai com a educação de seus filhos, mas esse documento evoca mais uma vez a responsabilidade educativa que recaía sobre os ombros de um tutor.6 Em

"Acredito que essa "ausência" possa ser explicada por diversos fatores, como a idade avançada em que eram redigidos, quando não mais havia crianças em idade de serem educadas; o imprevisto de muitas mortes, que talvez impedissem a preparação de um testamento; a "fraqueza humana" constantemente mencionada, isto é, quando o testador (ou testadora) afirmava nunca ter se casado, mas por "fraqueza humana" ter tido um ou 


\section{pro.posıções}

e-ISSN 1980-6248

27 de junho de 1888, na cidade de Curitiba, numa carta testamento, Adolpho Lindeman redigiu suas últimas vontades, e todas elas diziam respeito à educação de seus filhos:

Rogo com instância ao Dr. Juiz de Órfãos que entregue minha filha Maria a Dona Margarida Roscamp, para educa-la conforme suas posses, assim como a minha filha de nome Ester, entregará ao meu compadre de nome Pedro Henrichs, para educa-la [itálico adicionado] da melhor forma que puder. Outrossim, os meus filhos de nome Albrecht e Guilherme, desejo que sigam para a Europa a entregar à minha irmã Maria Marhenke, residente em Uslar, Alemanha e para este fim peço ao Sr. Dr. Juiz de Órfãos nomear Henrique Burmester para guiar estes dois menores nesta minha vontade de seguirem para a Europa. Espero que será cumprido este pedido.(Lindemann, 1888, s.p.)

Nas suas últimas vontades, Adolpho Lindeman expressou sua preocupação com o futuro dos filhos e, no caso específico de suas filhas, com uma educação que esperava receberem daqueles que nomeava como seus tutores. Ele responsabilizava, de forma bem clara, a Margarida Roscamp e Pedro Henrichs de incumbirem-se dessa tarefa. Mas seu testamento confirma-nos também que a morte do pai causava grandes mudanças na vida familiar: os irmãos seriam separados, passariam a residir em outras famílias e os meninos, inclusive, seriam mandados para o outro lado do oceano. Ademais, os tutores teriam que não apenas dar casa e alimento aos órfãos - o que sequer é mencionado aqui - mas, sobretudo, educá-los, segundo suas posses no caso da senhora Roscamp ou da melhor forma que pudesse, no caso do compadre Pedro.

Um outro exemplo: o viajante Salvador Correia Coelho, no retorno do passeio à sua terra natal em 1840, foi visitar o irmão que à época residia em Sorocaba. Também ali temos evidência de que a educação era responsabilidade dos tutores: por "falecimento de seu sogro em 1836 [meu irmão] encarregou-se não só do tráfego da casa comercial; mas de fazer educar os seus cunhados que ficaram em tenra idade; nesta missão dupla não desmentiu o seu caráter" (Coelho, 1995, p. 104).

outro filho, ali ou acolá, quase sempre ilegítimos aos olhos do mundo e que só seriam assumidos após a morte do genitor; além do fato de que muitos pais, ao fim da vida, já tinham seus filhos falecidos, vítimas de alguma dentre as tantas doenças que ceifavam a vida dos pequenos paranaenses naquele tempo. 


\section{pro.posıções}

\section{Considerações finais}

As evidências examinadas ao longo deste artigo ofereceram alguns indícios sobre o que pais e mães faziam, quando davam a seus filhos uma educação no século XIX. Por um lado, demonstram a potencialidade do testemunho necrológico como fonte para a história da educação da criança pela família. Por outro, permitem que se construa, nessas considerações finais e a modo de conclusão, uma definição sobre em que consistia a educação da criança pela família naquele período, na Província do Paraná. É o momento, pois, de interpretar a "realidade opaca" (Ginzburg, 1989) que indícios, indagações e fontes mobilizadas permitem, nos limites deste texto, tentar decifrar.

Os necrológios insistem que a educação da criança pela família é obra primordial do pai e da mãe e, eventualmente, daqueles que fazem as suas vezes, um parente ou um tutor. Embora não definam essa educação - o que certamente não era intenção de nenhum dos autores dos elogios fúnebres -, apontam os sentidos e os significados que lhe eram atribuídos: na casa de Bento Guimarães, ela consistia em uma preparação para a vida (de caráter futuro); João Manoel de Paula (ou, no mínimo, seu necrologista) parecia entendê-la como a organização prática da vida familiar (de caráter presente e pragmático); Joana Hilária, aos olhos que a descreveram, educava seus filhos no amor à virtude, ensinando-os pela prática e pelo exemplo; já Balbina Ferreira de Siqueira fora educada por seus pais por meio dos bons hábitos de seus progenitores, ao passo que José Pereira Jorge transmitia à sua família os princípios da religião, aperfeiçoada pela prática da caridade.

A partir dos casos analisados, pode-se definir que a educação da criança pela família parece ter consistido numa prática social (porque punha em relação diferentes sujeitos) e cultural (porque aberta à diferentes apropriações), dada pelos pais aos filhos visando à aquisição de atitudes e comportamentos, ora caros à organização e às necessidades da família, ora vistos como baluarte para a sociedade em que viveram, a mesma para a qual agora seu empenho como educadores era narrado e fixado como ícones de uma vida exemplar. Por causa dessa importância, não se deve perder de vista que tal responsabilidade pesava também sobre os ombros do tutor, que, além de velar pelos bens dos órfãos sob seus cuidados, deveria vigiar e governar suas pessoas, o que só poderia ser feito a contento, por meio de uma educação adequada, semelhante à que recebiam dos pais. Educação pedida como última vontade por Adolpho Lindeman e que fora dada pelo irmão de 
Salvador Coelho aos seus pequenos cunhados órfãos. Educação da qual o testemunho necrológico é uma importante evidência.

\section{Referências Bibliográficas}

Bastos, M.H.C. (2006). A pesquisa em história da educação em revista. In A. Schelbauer, I. J. C. Lombard, \& M. C. Machado (Orgs.), Educação em debate: perspectivas, abordagens, historiografia (pp. 99-128). Campinas: Autores Associados.

Bloch, M. (2011) A apologia da história ou o ofício do historiador. Rio de Janeiro: Jorge Zahar.

Bluteau, R. (1728). Vocabulário português e latino... Coimbra: Cia de Jesus.

Bourdieu, P. (2001). A ilusão biográfica. In J. Amado, \& M. de M. Ferreira (Orgs.), Usos e abusos da bistória oral (pp.183-191). Rio de Janeiro: Editora da FGV.

Chartier, R. (2002) A história cultural entre práticas e representações. Lisboa: Difel.

Coelho, S. J. C. (1995). Passeio à minha terra. Curitiba: Farol do Saber.

Conselheiro Fiel do Povo (1860). Rio de Janeiro: Laemmert.

Duby, G. (1989). O prazer do historiador. In P. Nora (Org.), Ensaios de ego-história (pp.109138). Lisboa: Edições 70.

Duby, G. (1993). A história continua. Rio de Janeiro: Jorge Zahar.

Elias, N. (2002). A solidão dos moribundos. Rio de Janeiro: Jorge Zahar.

Farge, A. (1999). Lugares para a história. Lisboa: Teorema. 


\section{pro.posıções \\ eISSN 1980-6248}

Faria Filho, L. M. (2008). O processo de escolarização em Minas Gerais: questões teóricometodológicas e perspectivas de análise. In T. N. L. Fonseca, \& C. G. Veiga, (Orgs.), História e historiografia da educaşão no Brasil (pp.77-98). Belo Horizonte: Autêntica.

Febvre, L.(1989). Combates pela história. Lisboa: Presença.

Febvre, L. (2009). O problema da incredulidade do século XVI: a religião de Rabelais. São Paulo: Companhia das Letras.

Fonseca, J. (1848). Dicionário da Lingua Portuguesa... Paris-Lisboa: Auilard-Bertrand.

Fonseca, T. N. L. (2011) (Org.). As reformas pombalinas no Brasil. Belo Horizonte: Mazza.

Freyre, G. (1963). O escravo nos anúncios de jornais brasileiros do século XIX. Rio de Janeiro: Global.

Gilies, A.M.R. (2014). O diário de uma imigrante britânica no Paraná (1860-1890). Memórias, trabalho e sociabilidades. Curitiba: Museu Paranaense.

Ginzburg, C. (1989). Sinais: raízes de um paradigma indiciário. In Mitos, Emblemas, Sinais (pp. 143-180). São Paulo: Companhia das Letras.

Ginzburg, C. (2008). O queijo e os vermes. O cotidiano e as ideias de um moleiro perseguido pela inquisição. São Paulo: Companhia das Letras.

Gondra, J.G.; Schueller, A. F. M. (2008). Educação, poder e sociedade no império brasileiro. São Paulo: Cortez.

Gouvêa, M. C. S. (2004). Tempo de aprender: a produção histórica da idade escolar. Revista Brasileira de História da Educação, 8, 265-288.

Inácio, M. S., Faria Filho, L., Rosa W., \& Sales, Z. E.(Orgs.) (2006). Escola, política e cultura. Belo Horizonte: Argumentum.

Kuhlmann Jr., M. (1999). Raízes da historiografia educacional brasileira (1881-1922). Cadernos de Pesquisa, 106, 159-171.

Le Goff, J. (2003). História e memória. Campinas: Editora da Unicamp. 


\section{pro.posições \\ eISSN 1980-6248}

Levi, G. (1991). Sobre a micro-história. In P. Burke, A escrita da história. Novas perspectivas. São Paulo: Unesp.

Lindemann, A. (1888). Carta Testamento. Departamento de Arquivo Público do Paraná. Fundo Poder Judiciário, manuscrito.

Lopes, E. M. S., \& Galvão, A. M. O. (2010). Território plural: a pesquisa em história da educação. São Paulo: Ática.

Miguel, M. E. B. (2011). Práticas escolares e processos educativos na escola provincial paranaense (1954-1889). In W. Gonçalves Neto, M. E. B. Miguel, \& A. Ferreira Neto (Orgs.), Práticas escolares e processos educativos: currículo, disciplinas e instituições escolares (séculos XIX e XX) (pp. 179-204, Coleção: Horizontes da Pesquisa em História da Educação no Brasil, 4). Vitória: EDUFES.

Monarcha, C. (2007). História da educação (brasileira): formação do campo, tendências e vertentes investigativas, História da Educação. 21, 51-78.

Morais da Silva, A. (1813). Dicionário da Lingua Portuguesa... Lisboa: Typografia Lacerdiana.

Necrológio. (1859). O Dezenove de Dez̧embro. Curitiba, janeiro, 08.

Necrológio. (1861). Correio Oficial. Curitiba, dezembro, 20.

Necrológio. (1862). O Dezenove de Dezembro. Curitiba, dezembro, 24.

Necrológio. (1865). O Dez̧enove de Dez̧embro. Curitiba, março, 04.

Necrológio. (1868). O Dez̧enove de Dezembro. Curitiba, maio, 13.

Necrológio. (1870). O Dezenove de Dezembro. Curitiba, abril, 06.

Necrológio. (1871). O Dezenove de Dezembro. Curitiba, setembro, 06.

Necrológio. (1872a) O Dez̧enove de Dezembro. Curitiba, maio, 01.

Necrológio. (1872b). O Dez̧enove de Dezembro. Curitiba, setembro, 18.

Necrológio (1876a). A Provincia do Paraná. Curitiba, janeiro, 23.

Necrológio (1876b). A Provincia do Paraná. Curitiba, novembro, 13.

Necrológio. (1880). O Paranaense. Curitiba, janeiro, 18. 


\section{pro.posições \\ e-ISSN 1980-6248}

Nunes, C., \& Carvalho, M. M. C. (1993). História da Educação e fontes. Cadernos ANPED, $5,7-64$.

Nunes, J. H. (2006). Dicionários no Brasil. Análise e bistória do século XVI ao XIX. São Paulo: Pontes.

Thompson, E.P. (2009a). A miséria da teoria ou um planetário de erros. Curitiba: Copylex.

Thompson, E. P. (2009b). A venda de esposas. In Costumes em comum (pp.305-352). São Paulo: Companhia das Letras

Vasconcelos, M. C. C. (2005). A casa e seus mestres. Rio de Janeiro: Gryphos.

Veiga, C. G. (2008). Escola pública para os negros e pobres no Brasil: uma invenção imperial. Revista Brasileira de Educação, 13(39), 502-516.

Verdelho, T. (2002). Dicionários portugueses, breve história. In J. H. Nunes, \& P. Petter (Orgs.), História do saber lexical e constituição de um léxico brasileiro (pp.15-64, 1a ed.). São Paulo: Pontes.

Submetido à avaliação em 21 de março de 2016; aceito para publicação em 24 de abril de 2016. 